Elżbieta Przybył-Sadowska

Uniwersytet Jagielloński

eprzybyl@iphils.uj.edu.pl

\title{
Słodki uśmiech siostry Marii z Lasek
}

\author{
(S. Maria Bronisława od Kościoła Bożego Gołębiowska - \\ Miriam Wajngold)
}

\section{The Sweet Smile of Sister Maria of Laski}

Abstract: The article is devoted to the biography of Sr. Maria Gołębiowska from the congregation of the Franciscan Sisters Servants of the Cross, one of the more notable figures of the Catholic community bound with the Society for the Care of the Blind and a friend of the poet Jerzy Liebert. The text is focused on the religious aspect of the sister's life, including, in the first place, her path to conversion and joining the cloister, and also her further life, with special emphasis on the experiences during the World War II, when - as a Jew - she had to hide.

Keywords: Maria Gołębiowska, Bronisława Agnieszka Wajngold, Jerzy Liebert, Catholicism, Poland, Laski, intellectuals, history, interwar period, $20^{\text {th }}$ century

Streszczenie: Artykuł poświęcony biografii s. Marii Gołębiowskiej ze Zgromadzenia Sióstr Franciszkanek Służebnic Krzyża - jednej z ciekawszych postaci katolickiego środowiska skupionego wokół Towarzystwa Opieki nad Ociemniałymi w Laskach, przyjaciółce poety Jerzego Lieberta. W tekście ukazano przede wszystkim religijny aspekt jej biografii, w tym zwłaszcza jej drogę do nawrócenia i wstąpienia do zakonu, a także jej dalsze losy, ze szczególnym uwzględnieniem jej przeżyć podczas drugiej wojny światowej, gdy jako Żydówka zmuszona była się ukrywać.

Słowa kluczowe: Maria Gołębiowska, Bronisława Agnieszka Wajngold, Jerzy Liebert, katolicyzm, Polska, Laski, intelektualiści, historia, dwudziestolecie międzywojenne, XX wiek

Zygmunt Serafinowicz, jedna z bardziej znanych postaci katolickiego środowiska związanego z Towarzystwem Opieki nad Ociemniałymi z Lasek, rodzony brat poety Jana Lechonia, zwykł mawiać, że „Laski to nie tylko słodki uśmiech siostry Marii”. Rzeczywiście wielu spośród tych, którzy uważali Laski za swoją duchową ojczyznę, pozostawało pod urokiem s. Marii Gołębiowskiej. Byli wśród nich znani literaci, osobistości ze świata kultury i sztuki, filozofowie, naukowcy 
różnych dziedzin, ale też osoby zupełnie zwykłe, niczym się niewyróżniające. Siostra Maria wszystkich traktowała jednakowo. Kiedyś, gdy była przełożoną, przyszedł do klasztoru żebrak. Kiedy zobaczyła, że jedna z sióstr byle jak podała mu jedzenie, upomniała ją, mówiąc: „trzeba mu dać tak, jak się biskupowi podaje”. W jej obecności z łatwością można było poczuć ducha dawnych Lasek - tę gorliwość, która sprawiała, że ludzie gotowi byli porzucić wszystko, by wspólnie, klepiąc biedę, zmieniać na lepsze samych siebie oraz otaczający ich świat.

Biografia s. Marii wyraźnie dzieli się na kilka okresów, a każdy z nich jest opatrzony innym jej imieniem. Miała ich pięć. Rodzice nadali jej imię Bronisława, na chrzcie otrzymała imię Agnieszka, Jerzy Liebert przez pewien czas nazywał ją Anną, po wstąpieniu do Zgromadzenia Sióstr Franciszkanek Służebnic Krzyża w Laskach przyjęła imię Miriam, które w czasie wojny zmieniła na Marię (nazwisko zaś z Wajngold na Gołębiowska). Z każdym z nich wiąże się inna historia, a ich odsłanianie pokazuje, jak skomplikowana była osobowość tej niezwykłej kobiety.

Urodziła się 11 grudnia 1902 roku w Warszawie w zamożnej żydowskiej rodzinie. O jej rodzicach, Icku i Idessie ze Szladowerów Wajngold, nie wiemy zbyt wiele. Garść wspomnień z dzieciństwa, jakimi s. Maria podzieliła się z siostrami ze zgromadzenia w 1976 roku $^{2}$, świadczy o tym, że wyrosła w kochającej się i wierzącej rodzinie ${ }^{3}$. Po ich śmierci Bronisława wychowywała się w domu starszej o 26 lat siostry Heleny i jej męża - Leona Kranca, razem z trójką ich dzieci. Mieszkali w Warszawie. Leon Kranc był współwłaścicielem warszawskiej fabryki odlewów „Kranc i Łępicki”, w której powstawały między innymi odlewy rzeźb Xawerego Dunikowskiego, Henryka Kuny i Edwarda Wittiga ${ }^{4}$. Uczyła się na pensji i jak większość ówczesnych uczniów uzupełniała swoją edukację w konspiracyjnych kółkach samokształceniowych. Tak poznała swoją najbliższą przyjaciółkę - Zofię Steinberg (późniejszą s. Katarzynę z Lasek), która organizowała te kółka w jej szkole. Być może pod jej wpływem w czasie studiów zaczęła działać w Polskiej Partii Socjalistycznej. Oddawała się tej działalności z wielkim zapałem, skoro pamiętano jej to jeszcze wiele lat później. „Dowiedziałem się - pisał Jerzy Liebert w jednym ze swoich listów do niej - że jakiś Twój podobno stary przyjaciel, a niejaki Koral, rozpowiada o Tobie dziwnie przygnębiające rzeczy, a mianowicie: »że jesteś fanatyczką, kobietą straszną, która boso chodziła

${ }^{1}$ Homilia ks. Tadeusza Fedorowicza podczas mszy św. pogrzebowej za śp. s. Marię Gołębiowską w Laskach, 15 grudnia 1984, mps, Archiwum Franciszkanek Służebnic Krzyża w Laskach (dalej: AFSK), sygn. 452 (s. Maria Gołębiowska - Miriam Wajngold).

2 Opowiadanie s. Marii Gołębiowskiej z okazji pięćdziesiątej rocznicy jej ślubów zakonnych zostało nagrane na taśmie magnetofonowej, spisane i opublikowane w książce Ludzie Lasek. Zob. Tak się zaczęto... (Z teki archiwalnej siostry Marii) [w:] Ludzie Lasek, oprac. i wstęp T. Mazowiecki, Warszawa 2000, s. 456-464.

3 Tamże.

${ }^{4}$ J. Liebert, Listy do Agnieszki, red. S. Frankiewicz, Warszawa 2002, s. 34, przyp. 1. 
na Wolę propagować wzniosłe idee komunizmu"”s. Studiowała dziennikarstwo w Wolnej Wszechnicy Polskiej i uczyła się malarstwa w Szkole Sztuk Zdobniczych.

Jerzego Lieberta ${ }^{6}$ poznała na przełomie 1922 i 1923 roku na spotkaniu poświęconym głośnemu czytaniu poezji ${ }^{7}$ Miała wówczas lat dwadzieścia, on był od niej o dwa lata młodszy. Oboje, zafascynowani poezją Skamandrytów ${ }^{8}$, zwłaszcza wierszami Antoniego Słonimskiego i Jana Lechonia, z zapamiętaniem oddawali się pisaniu wierszy. Zamiłowanie do poezji legło u podstaw przyjaźni, która stała się zaczątkiem ich dalszych, odtąd już wspólnych poszukiwań. Te zaś, głównie dzięki Bronisławie, najpierw koncentrowały się na motywie „walki o autentyczność i prostotę uczuć, o prawdziwość nazywającego je języka, a także coraz wyraźniejszej tęsknocie za nową, czystą miłością" ", by z czasem coraz mocniej skupić się na kwestiach duchowych. Ostatecznie doprowadziły one oboje do przełomu religijnego - Lieberta do odnowienia wiary, Bronisławę do przyjęcia chrztu, a potem do wstąpienia do Zgromadzenia Sióstr Franciszkanek Służebnic Krzyża w Laskach.

Dzieje tej przyjaźni nie poddają się łatwo ani opisowi, ani tym bardziej ocenie. Jedni - jak choćby Wisława Szymborska - chcieli w niej widzieć „uczucie (...) natury intelektualnej" ${ }^{10}$, inni, na przykład Stefan Frankiewicz, wydawca listów Jerzego Lieberta do Agnieszki i jej wieloletni przyjaciel, nie wahali się pisać o wielkiej miłości poety ${ }^{11}$. Rację mają i jedni, i drudzy. „Spotkanie Agnieszki i Lieberta - pisał Stefan Frankiewicz - nie inicjowało bynajmniej od razu młodzieńczej miłości; poeta podkochiwał się w tym czasie w jakiejś pensjonarce" ${ }^{12}$.

5 Tamże, s. 35.

${ }^{6} \mathrm{Na}$ temat Jerzego Lieberta, zwłaszcza w kontekście jego religijnych poszukiwań, zob.: A.M. Szczepan-Wojnarska, „...Z ogniem będziesz się żenit”. Doświadczenie transcendencji w życiu i twórczości Jerzego Lieberta, Kraków 2003; S. Misiniec, Ślady na niebie. Duchowa droga Jerzego Lieberta, Kraków 1997; P. Nowaczyński, Studia z literatury XX wieku, Lublin 2004; E. Wiśniewska, Jerzy Liebert $w$ mistycznej walce o stowo, „Przegląd Powszechny” 1982, nr 5; Z. Lichniak, Poeta konsekwencji. Rzecz o Jerzym Liebercie, Warszawa 1952.

${ }^{7}$ Stefan Frankiewicz jako datę pierwszego ich spotkania podaje rok 1922, jednak sama s. Maria w swoich wspomnieniach przywołała datę 1923. Zob. S. Frankiewicz, Wstęp [w:] J. Liebert, Listy do Agnieszki, dz. cyt., s. 10; por. Tak się zaczęto..., dz. cyt., s. 457.

${ }^{8}$ Wśród wielu publikacji na temat Skamandrytów zob. na przykład: J. Marx, Skamandryci: Julian Tuwim, Kazimierz Wierzyński, Jarostaw Iwaszkiewicz, Antoni Stonimski, Jan Lechoń, Stanistaw Balinski, Warszawa 1993; W. Ligęza, Epitafia dla skamandrytów, Kraków 1996; serię „Skamander” wydawaną przez Uniwersytet Śląski w Katowicach - ostatni numer: Reinterpretacje, „Skamander”, t. 11, red. M. Tramer, A. Wójtowicz, Katowice 2015; Stulecie skamandrytów, red. K. Biedrzycki, Kraków 1996; a także: Meandry skamandrytów, red. W. Appel, Toruń 2011. Szerzej i bardziej popularnie o kręgu Skamandra jako o warszawskim zjawisku kulturowym: L. Sadkowska-Mokkas, Warszawa Skamandrytów, Warszawa 2016.

9 S. Frankiewicz, Wstęp, dz. cyt., s. 11.

10 Tamże, s. 16.

11 Tamże, s. 16-17.

12 Tamże. 
Jeśli w ich rozmowach pojawia się słowo miłość, to raczej w kontekście miłości czystej, a więc Mitości doskonatej, jak Liebert zatytułował jeden ze swoich wierszy z tomu Druga ojczyzna ${ }^{13}$. Tęsknota za czystością uczuć i umiejętnością ujęcia ich językiem poezji u obojga szybko przeszła z płaszczyzny literackiej w sferę codziennego życia i jego doświadczania, by potem ewoluować we wspólnie podjęte poszukiwania religijne. Te zaś z kolei odciskały swe piętno na ich poezji.

Bronisława i Jerzy zdają się wówczas mówić niemal o tym samym, językiem tak podobnym, że gdy po śmierci poety wydano ostatni tom jego poezji (Kotysanka jodtowa, 1932), znalazł się w nim także wiersz Bronisławy (Modlitwa $\left.{ }^{14}\right)$ i nikomu wówczas nawet do głowy nie przyszło, że mógł go napisać ktoś inny ${ }^{15}$. Własną twórczość traktowali zresztą jak dobro wspólne - świadomie i za obopólną zgodą zapożyczają od siebie fragmenty wierszy, jakby były one przedłużeniem dialogu, który ze sobą prowadzili. Świadczy o tym choćby fragment listu Lieberta do Agnieszki z 22 grudnia 1925 roku:

Dziękuję Ci bardzo, że pozwalasz zabrać sobie kawałek wiersza. Wiesz, Agnusie, że i ja tak samo straciłem wobec Ciebie poczucie prawa własności. Myślałem sobie, że przecież nie ma nic naturalniejszego nad to, że słowa nasze należą do nas wspólnie. I nie wiesz nawet, jak głęboko i silnie tkwi to we mnie ${ }^{16}$.

Tę poetycką harmonię najlepiej widać, gdy się zestawi ze sobą ich wiersze powstałe w tym okresie. Pierwszy z nich jest autorstwa Jerzego Lieberta, drugi wyszedł spod pióra Bronisławy Wajngold:

\author{
Modlitwa \\ Panie, który mnie ciszą poisz i karmisz błękitem, \\ I gwiazdy mi otrząsasz, księżyce z jabłoni, \\ I Twój wieczór mi dobry dobrą łąką dzwoni, \\ I niebem gwiazdy nocą przesiewasz jak sitem. - \\ O, zabierz z słów mych smętnych, jak sznur ptaków lotnych, \\ tę tęsknotę błękitną i marzeń mych męstwo, \\ Oczu zwątpienie wieczne i ludzkie - wilgotnych, \\ Wszak, Panie, z tego świata jest moje królestwo.
}

13 J. Liebert, Mitość doskonata [w:] tegoż, Druga ojczyzna, Warszawa 1925, s. 20.

${ }_{14}$ Tenże, Kotysanka jodtowa, Warszawa 1932, s. 50.

15 Źródłem tej informacji jest z pewnością sama s. Maria. O tej pomyłce wielokrotnie, choć dość oględnie, wspominał jej przyjaciel i znawca twórczości Lieberta - Stefan Frankiewicz (zob. na przykład S. Frankiewicz, Agnieszka [w:] Ludzie Lasek, dz. cyt., s. 449), by w końcu, we wstępie do wydanego przez „Więź” w 2002 roku zbioru listów Lieberta do Agnieszki napisać wprost, że chodzi właśnie o Modlitwę. Por. S. Frankiewicz, Wstęp, dz. cyt., s. 12.

16 J. Liebert, Listy do Agnieszki, dz. cyt., s. 283. 
Odsuń ode mnie źrenic Twych ogień i morze.

Ogień, co pali, morze, co chłodzi w ukryciu -

O, zatop nim głębinę, w którą schodzą zorze,

I, jak duszę miłości, tak mnie wydaj życiu ${ }^{17}$.

Wszystkie owoce ziemi i owoce nieba,

Któreś stworzył ku chwale swojego Imienia,

Przykładasz do ust naszych, jak kawałek chleba,

Gdy są głodne, ochładzasz, gdy spragnione cienia.

Pożeramy zuchwale Twe dobrotliwości,

Które trwalsze się zdają niż zorze i zmierzchy,

Ku wygodzie się naszej Twa litość uprości,

Tym większą się nam wyda, im większe są grzechy.

Byśmy wreszcie, zerwane Twą ręką owoce,

O Boże, coś nam kwitnąć i dojrzewać kazał,

Trwali - syte wieczności mając dnie i noce,

Lub przez ciemność połknięci własnych serc zarazą ${ }^{18}$.

Jak bardzo wspólne były ich ówczesne poszukiwania widać także w późniejszych wspomnieniach s. Marii:

Jakoś tak równocześnie zaczęły nas interesować sprawy religijne. Zaczęliśmy szukać jakiś książek religijnych. Wtedy, idąc kiedyś Nowym Światem, zobaczyłam wysiadającą z tramwaju siostrę Katarzynę [Zofię Steinberg - przyp. E.P.S.]. (...) Nie umiem sobie dobrze przypomnieć, ale wydaje mi się, że musiało to być wiosną 1924 roku. (...) powiedziałam: „Zosiu, powiedz, gdzie można dostać jakieś książki religijne!” Ona się uśmiechnęła tak ślicznie i powiedziała: „To idź na Litewską 6, tam zapytaj się o Zosię Landy”. (...) Wtedy właśnie Zosia Landy zaczęła nam pożyczać książki. Zaczęliśmy oboje przychodzić do biblioteki ${ }^{19}$.

Bardzo znamienne jest to, że mówiąc o tych doświadczeniach, zawsze używała liczby mnogiej.

17 Tenże, Modlitwa [w:] tegoż, Pisma, t. 1: Poezje, Warszawa 1934, s. 35.

18 S. Maria Gołębiowska, Wiersze, mps, s. 3, AFSK, sygn. 452 (s. Maria Gołębiowska s. Miriam Wajngold). Wiersz był także cytowany przez S. Frankiewicza we wstępie do: J. Liebert, Listy do Agnieszki, dz. cyt., s. 11.

19 Tak się zaczęto..., dz. cyt., s. 457. 
Bibliotekę Wiedzy Religijnej, ponieważ o niej tutaj mowa, powstałą z inicjatywy ks. Władysława Korniłowicza, założyła Irena Tyszkiewiczowa ${ }^{20}$. Wkrótce potem zaczęli się w niej pojawiać młodzi szukający wiary ludzie, wśród których była też jedna z najciekawszych postaci tego środowiska - Zofia Landy, późniejsza s. Teresa. Dla Bronisławy Wajngold kontakt z Zofią był niezwykle ważny. Obie wywodziły się z rodzin żydowskich, wcześniej były socjalistkami, wreszcie obie też do środowiska skupionego wokół Biblioteki przywiodło poszukiwanie wiary. Być może to właśnie ona wypożyczyła Bronisławie wybór pism Johna H. Newmana Przyświadczenia wiary z przedmową Stanisława Brzozowskiego - książkę, która zmieniła życie i jej, i Jerzego Lieberta. W roku 1977 opowiadała:

Dla mnie to była chyba najważniejsza chwila mojego życia. Nagle dowiedziałam się, że istnieje jakiś świat nadprzyrodzony, że poza tym światem, który widzimy, jest jakiś świat niewidzialny, niepojęty, ale żywy i że w tym świecie jest Chrystus. I że Chrystus jest czymś więcej niż człowiekiem. (...) A poza tym dowiedziałam się, że jest Kościół ${ }^{21}$.

Po tylu latach, bo od opisywanych wydarzeń, gdy o nich opowiadała, dzieliło s. Marię ponad pięćdziesiąt lat, w jej słowach ciągle jeszcze było słychać tamtą fascynację - tamto zachłyśnięcie się odkryciem wiary, silniejszej niż jakiekolwiek uczucie, jakiego dotąd doświadczyła.

Odkryta przez nią wiara domagała się uczynków. Poprosiła więc Lieberta, by nauczył ją się modlić. On sam pochodził wprawdzie z katolickiego domu, ale, podobnie jak większość młodych ludzi w tym czasie, nie był religijny ${ }^{22}$. Został ochrzczony, ale „wszystko to było dla niego nieżywe”23. Jednak i jego lektura Newmana nie pozostawiła obojętnym. Zaczął na nowo odkrywać wiarę, w której został wychowany, a którą dotąd traktował raczej jako coś oczywistego. Teraz zaś stała się ona dla niego ciągłym wyzwaniem do stawania się lepszym chrześcijaninem. Była czymś, co wymagało uwagi i stałych zmagań z samym sobą, z „gburem”, jakiego w sobie znajdował. Więcej, ta na nowo odkryta wiara bez przerwy domagała się pogłębiania zarówno pod względem intelektualnym, jak i duchowym, a jednocześnie - przynajmniej dla Jerzego Lieberta, o czym świadczą jego listy do Agnieszki - nieustannego wzajemnego motywowania się do dalszych wysiłków. W jednym z nich pisał:

${ }^{20}$ E. Przybył-Sadowska, Biblioteka Wiedzy Religijnej w Warszawie (1919-1939), „Z Badań nad Książką i Księgozbiorami Historycznymi” 2016, nr 10, s. 211-228; taż, Triuno. Instytucje we wspólnocie Lasek 1911-1961, Kraków 2015, s. 173-182.

${ }^{21}$ Tak się zaczęto..., dz. cyt., s. 458.

22 Stosunek ówczesnych kręgów intelektualnych do katolicyzmu, od obojętnego po otwarcie negatywny, a także jego głębokie korzenie dobrze ukazuje Bohdan Cywiński w swojej słynnej książce Rodowody niepokornych, Warszawa 2010.

${ }^{23}$ Tak się zaczęto..., dz. cyt., s. 458. 
Teraz dopiero widzę, jak każde słowo Twoje przeznaczone jest dla mnie i że chyba już nigdy nie będzie inaczej. O obowiązkach moich nie musisz mi przypominać. Sam czuję coraz lepiej, że żyć inaczej byłoby niemożliwe. (...) Ty w tej chwili jesteś silniejsza i wyższa ode mnie o całą wiarę, więc podnieść się do Ciebie jest moim najgorętszym pragnieniem ${ }^{24}$.

Bronisławie jednak nie wystarczały wyłącznie intelektualne poszukiwania. Książka Newmana, jak sama twierdziła, ukazała jej, czym jest Kościół, więc bycia we wspólnocie wiernych pragnęła najbardziej, nawet jeśli wówczas nie umiała tego jeszcze dobrze nazwać. Nie mówiąc nic nikomu, zaczęła chodzić do kościoła. Klękała, gdy inni klękali, wstawała, gdy wstawali, ale zupełnie nie rozumiała, co się właściwie dzieje. „Nie umiałam - mówiła - sobie tego wszystkiego jakoś pogodzić” 25 . Tej narastającej potrzeby uczestnictwa w życiu liturgicznym Kościoła - co ciekawe - Liebert w niej nie dostrzegł. Zauważyła to właścicielka Biblioteki Wiedzy Religijnej - Irena Tyszkiewiczowa. „Była dla mnie i dla Lieberta taka delikatna - wspominała po latach s. Maria. Nie napomykała o niczym, a jednocześnie miałam poczucie jakiejś ogromnej otwartości i serdeczności" ${ }^{26}$. Zaproszenie do wejścia w nowy świat również było niezwykle delikatne. Pewnego dnia po prostu zaprosiła Bronisławę na uroczystość poświęcenia biblioteki, która odbyła się 17 maja 1925 roku.

Zaproszenie było niezobowiązujące. Bronisława mogła je potraktować albo jako coś kurtuazyjnego, albo jako zaproszenie do większego religijnego zaangażowania i wejścia w krąg osób związanych z ks. Władysławem Korniłowiczem i Matką Elżbietą Czacką ${ }^{27}$. Tyszkiewiczowa poprosiła Bronkę jedynie o to, by odbyła rozmowę z o. Jackiem Woronieckim, który bibliotekę święcił. Woroniecki - jak później twierdziła s. Maria - nie zrobił na niej wielkiego wrażenia. Przyznała mu się, że chciałaby przyjąć chrzest, ale że o chrześcijaństwie „właściwie nic nie wie i nic nie rozumie”. Sytuację komplikowało to, że rodzina Bronisławy wcześniej podjęła decyzję o przeprowadzce do Francji i właściwie nie było czasu, by przygotować ją do chrztu. Mogła dostać jedynie listę książek i adres klasztoru we Francji, gdzie miała uzyskać pomoc.

Po kilku dniach Irena Tyszkiewiczowa znów zaprosiła Bronisławę, tym razem na mszę do domowej kaplicy. Siostra Maria wspominała: „Przyszłam i to była druga chwila wielkiej łaski, dlatego, że nie rozumiejąc sensu [mszy św. - przyp. E.P.S.], w każdym razie tyle zrozumiałam, że Pan Bóg przyszedł

${ }^{24}$ J. Liebert, Listy do Agnieszki, dz. cyt., s. 72-73.

${ }^{25}$ Tak się zaczęto..., dz. cyt., s. 458.

26 Tamże, s. 458-459.

${ }^{27} \mathrm{Na}$ temat założycieli Lasek zob. przede wszystkim: s. T. Landy, s. R. Wosiek, Ksiądz Wtadystaw Kornitowicz, Warszawa 2003; E. Jabłońska-Deptuła, Matka Elżbieta Czacka i dzieto Lasek, Lublin 2002. 
na ołtarz. Strasznie wtedy płakałam, zdawało mi się, że szkoda, że ja dopiero teraz to zrozumiałam" ${ }^{\prime 2}$. To silne przeżycie sprawiło, że nie chciała dłużej czekać z przygotowaniami do chrztu. Zdecydowano więc, że będzie ją do chrztu przygotowywać Zofia Landy. Ta decyzja chyba najlepiej pokazuje otwartość środowiska. W świat chrześcijaństwa miał ją wprowadzać nie ksiądz albo katolik „z urodzenia”, choć takich osób w tym środowisku nie brakowało, ale niedawna konwertytka, czyli osoba, która przeszła podobną drogę i dobrze rozumiała, czego Bronisława doświadcza i potrzebuje. „Miałam - nie pamiętam - osiem czy dziesięć takich lekcji - wspominała s. Maria. - Myślę, że to było też jakieś światło, jakaś łaska, bo wszystko wydawało mi się takie zrozumiałe. Nie miałam trudności, wszystko przyjmowałam tak, jakbym była małym dzieckiem; wszystko wydawało mi się jakieś takie mądre, logiczne, słuszne i tak mi się związało ze Starym Testamentem”29.

Wówczas też trafiła do Kółka tomistycznego - grupy zgromadzonej wokół ks. Korniłowicza, która spotykała się, by wspólnie dyskutować o kwestiach teologicznych i filozoficznych ${ }^{30}$. Wzięła udział zaledwie w jednym czy dwóch spotkaniach, ale Korniłowicza, który mieszkał wówczas w Lublinie, wówczas nie spotkała. Wielkie wrażenie zrobił na niej natomiast Rafał Marceli Blüth - krytyk literacki, znawca literatury polskiej i rosyjskiej, a także ceniony eseista, postać nietuzinkowa ${ }^{31}$. Sam Blüth również był konwertytą, dlatego doskonale rozumiał rozterki Bronisławy. Pewnego razu, gdy wspólnie wracali ze spotkania Kółka, stwierdził po prostu: „nie rozumiem, dlaczego pani tyle czasu chce czekać, tyle komunii świętych straconych (...)"32. Szczerość i żarliwość bijąca z tych słów sprawiła, że postanowiła od razu przyjąć chrzest. Uroczystość odbyła się 18 czerwca 1925 roku w kaplicy przy kościele Świętego Krzyża. Wcześniej jednak o. Wilhelm Michalski, biblista i znany warszawski rekolekcjonista, który - pod nieobecność ks. Korniłowicza - miał go jej udzielić, szczegółowo przeegzaminował kandydatkę. Wśród osób obecnych na chrzcie s. Maria wymieniła Zofię Steinberg, Zofię Landy, swojego szwagra - Leona Kranca (jej siostra zmarła niecały miesiąc wcześniej), a także Irenę i Józefa Tyszkiewiczów, którzy byli jej rodzicami chrzestnymi. We wspomnieniach s. Marii nie pojawiło się nazwisko Lieberta, ale raczej trudno sobie wyobrazić, by go tam nie było. Na chrzcie otrzymała imię Agnieszka. Kolejnego dnia w kaplicy domu Tyszkiewiczów

${ }_{28}$ Tamże, s. 460. Podobny, niezwykle emocjonalny zapis dotyczący wspomnień z tego wydarzenia znajdujemy w jej notatkach osobistych pod datą 15 lipca 1979 roku, zob. s. Maria Gołębiowska, Pamiętnik 1978-1980, rps, AFSK, sygn. 452 (s. Maria Gołębiowska - Miriam Wajngold).

29 Tak się zaczęto..., dz. cyt., s. 460.

30 Więcej na temat Kółka w rozdziale mu poświęconym w mojej książce: Triuno..., dz. cyt., s. 183-193.

${ }^{31}$ K. Górski, Rafat Marceli Blüth [w:] Ludzie Lasek, dz. cyt., s. 202-210.

32 Tak się zaczęto..., dz. cyt., s. 460. 
bp Adolf Szelążek udzielił jej sakramentu bierzmowania, a już następnego, czyli 20 czerwca 1925 roku, wyjechała z rodziną do Cammazou we Francji, gdzie miała pomagać szwagrowi w prowadzeniu domu.

Pobyt we Francji był dla niej niezwykle trudny. Stosunki z rodziną nie układały się najlepiej, praca i warunki życia były trudne. Siostra Maria, wspominając te czasy, wskazywała raczej, że źródłem jej problemów mogło być jej przejście na katolicyzm i brak zrozumienia ze strony rodziny: „Mimo żeśmy się kochali i wszyscy byli dla mnie dobrzy, wiedzieli, że ja już jestem chrześcijanką i powstał jakiś przedział między moją rodziną a mną"33. W kraju zostawiła nie tylko najlepszego przyjaciela i towarzysza swoich duchowych poszukiwań, osobę bez wątpienia jej wówczas najbliższą, ale także te, które całkiem niedawno stały się dla niej ważne - Irenę Tyszkiewiczową, którą do końca życia nazywała swoją matką, czy Zosię Landy, która tak prosto i jasno umiała wytłumaczyć jej wszystko to, czego ona sama dotąd wyjaśnić sobie nie umiała. Wprawdzie we Francji spotkała przyjaznych ludzi, którzy również starali się jej pomóc - siostry z pobliskiego klasztoru i proboszcza, o którym mówiła, że "poczciwie się nią zajął” - ale tęskniła za Warszawą.

Jej uczucia znajdują swoiste odbicie w listach Jerzego Lieberta - listach, które pisał do niej niemal codziennie. Tylko tak możemy dowiedzieć się o jej przeżyciach z tamtego okresu, bo swoje listy do Lieberta Agnieszka spaliła, gdy wstępowała do klasztoru. On zaś, doskonale wyczuwając jej potrzeby, pisał jej o wszystkim, co się działo w Warszawie - o nowych książkach i przedstawieniach teatralnych, o wydarzeniach towarzyskich i plotkach, szczególnie z kręgów literackich, a także o swoich „korkach” (czyli korepetycjach), problemach z wezwaniem do wojska, kłopotach finansowych, a przede wszystkim o swoich lekturach i fascynacjach literackich. Pisał też, na wyraźną prośbę Agnieszki, o tym, co się dzieje w Bibliotece Wiedzy Religijnej przy ul. Litewskiej i w Kółku, z którego członkami poznała go, zanim wyjechała: „oni - pisał w październiku 1925 roku z myślą o warszawskich literatach - straszne rzeczy wyobrażają sobie o Blüthcie, o Litewskiej i o tych katolikach, którzy głośniejsi są w Warszawie, niż to się zdaje. Nie masz pojęcia siostrzyczko, jak to zabawnie wygląda, gdy o tych ludziach najdroższych, najlepszych pod słońcem, mówi się z tajemniczą miną, jak o konspiratorach i jakiś fanatykach" ${ }^{34}$. Ona zaś, w odpowiedzi, pisała: „Bliżsi mi jesteście niż rodzina (...)”35. Słowa te znajdujemy w jedynym znanym dziś jej liście do Lieberta, który zupełnym przypadkiem się zachował i został niedawno odkryty w Archiwum FSK.

33 Tamże, s. 461.

34 J. Liebert, Listy do Agnieszki, dz. cyt., s. 196.

35 T. Cwalina, List Agnieszki, „Laski. Pismo Rehabilitacyjno-Społeczne z Życia Dzieła Matki Elżbiety Róży Czackiej” 2004, nr 6, s. 124-128. Por. też taż, Kartki z cmentarza, WarszawaLaski 2010, s. 116. List zachował się w dokumentach s. Katarzyny Steinberg. AFSK, sygn. 452 (s. Maria Gołębiowska - Miriam Wajngold). 
Trwające ponad rok rozstanie nie tylko nie przerwało więzi łączącej Agnieszkę i Jerzego, ale nawet jeszcze bardziej ją wzmocniło. Proces ich wspólnego dojrzewania trwał nadal, choć dzieliły ich tysiące kilometrów i różne życiowe doświadczenia. Liebert w tym czasie zbliżył się do Kółka ks. Korniłowicza i zaprzyjaźnił się z Blüthem, z którym przecież łączyło go najwięcej. Blüth, z którym dzielił nie tylko religijną gorliwość, ale także pasje literackie, napisał o nim później:

Kiedyśmy się poznali akurat sześć lat temu, przyszedł do naszej gromadki i jako nowy człowiek, i jako nowy element twórczy. Przyniósł ze sobą głęboką wiedzę o poezji, o sztuce. Tym swoim nowym przyjaciołom tłumaczył cierpliwie, na czym polega czar poetyckiego słowa, i bronił niezależności poezji. Nauczył nas wszystkich, ludzi rozmaitych powołań i dziedzin - prawdziwego męskiego szacunku dla nowych poetyckich dróg ${ }^{36}$.

Śladem tych dyskusji o poezji, jakie za jego przyczyną toczyły się wówczas w Kółku, jest wiersz Poeci z 1926 roku, dedykowany Zosi i Antkowi (czyli Zofii Landy, późniejszej s. Teresie, i Antoniemu Marylskiemu):

To wiatr wieczny z Ciebie wiejący

Przypadł ku nam i o nas zaczepił,

Wywiał język słowem naglącym

I język ze słowem zlepił.

Drogi Tobie ten szum, szelest piersi,

Boś Ty sam w bryłę gliny dmuchał -

To nieprawda, byś Ty poetów

Nie kochał, ich słów nie słuchał $(\ldots)^{37}$.

W tym samym czasie Liebert pisał do Agnieszki:

Nigdy nie myślałem, że potrafię zżyć się tak bardzo z tymi ludźmi i tak ich pokochać. Czuję ciągłą chęć obcowania z nimi i przebywania wśród nich. A tak się jakoś układa szczęśliwie, że zawsze parę razy na tydzień widuję się czy to z Zosią [Landy przyp. E.P.S.], czy Irenką [Kaliską - przyp. E.P.S.] lub Rafałem [Blüthem - przyp. E.P.S.]. Brak tylko Ciebie, najdroższa, a rodzina byłaby cała ${ }^{38}$.

Rok spędzony z dala od Agnieszki uświadomił Liebertowi jego uczucia. „Tęskno mi bardzo za Tobą - pisze - i jednak nic nie jest w stanie tej pustki

${ }^{36}$ Cyt. za: W. Smaszcz, Habitus poetycki Jerzego Lieberta [w:] J. Liebert, Poezje wybrane, Warszawa 1996, s. 196.

${ }^{37}$ J. Liebert, Kotysanka jodtowa, dz. cyt., s. 41.

38 Tenże, Listy do Agnieszki, dz. cyt., s. 326. 
zapełnić. Jest coś niedokończonego w życiu moim bez Ciebie. Mam wrażenie, że okradamy się ze siebie nawzajem”39, a innym razem: „kocham Cię niedobrze, bo zbyt chcę Cię mieć dla siebie" ${ }^{40}$. Przyjaźń przerodziła się w gorącą miłość, tej jednak towarzyszyła swoista niepewność:

Smutno mi, ukochana, po Twoim liście. Tak przyzwyczaiłem się i zżyłem z myślą, że kiedyś ułożą się warunki i będziemy mogli razem mieszkać, iż gdy piszesz mi o Twoim zamilknięciu i mojej przyszłej rodzinie, naprawdę zaczynam się lękać, czy moja miłość Cię nie obraża, czy powinienem przed Tobą Ciebie tak kochaćć

Czytając listy Lieberta, nie mamy wątpliwości, że Agnieszka go kochała, ale czy była to taka miłość, jakiej wówczas od niej oczekiwał, czy też raczej wielokrotnie przez nią deklarowane uczucia siostrzane? Tej tajemnicy nigdy nie poznamy. Zakrywa ją milczenie s. Marii. Możemy jedynie powtórzyć to, co po wielu latach wyznała swojej przyjaciółce: „Sama przeżyłam piękną przyjaźń z Jerzym Liebertem, której nie zmącił ani jeden pocałunek, jakim przemawia miłość między mężczyzną a kobietą”ł2.

Kto jednak wie, jak potoczyłyby się losy tych dwojga, gdyby nie jedno wydarzenie, które zmieniło wszystko. Po latach s. Maria wspominała:

19 marca weszłam tam [w Cammazou - przyp. E.P.S.] do kościoła parafialnego, o niczym jeszcze nie myśląc. I nagle coś takiego się we mnie zrobiło, że zapragnęłam zostać zakonnicą. To jest coś najdziwniejszego w świecie, bo ja przecież tego nie chciałam. I potem nagle chciałam. Jak to się może w człowieku zmienić? Zapytywałam sama siebie: ale przecież ja tego nie chcę - nie, już to chcę ${ }^{43}$.

Chciała wstąpić do klasztoru dominikanek w Prouilh, jednak nie została przyjęta. Liebert pisał do niej wówczas:

Myślę sobie, że gdziekolwiek Bóg Cię zabierze - ofiara Twoja będzie przyjęta. Wiem tylko, że tutaj jesteś potrzebna, żeśmy powinni łączyć się w zwykłym sensie tego słowa, że Bóg potrzebuje tu pracy ludzi i choćby Cię prowadził różnymi drogami, przyprowadzi tutaj. To, co widziałem w Laskach i na Polnej, to, co widzę w naszym Kółku, w całym naszym ruchu, który Pan Jezus prowadzi - pozwala mi tak mówić, choć wiem dobrze, że to jest myślenie ludzkie, które spraw Bożych nie pojmie nigdy (...). To jest wszystko, co wiem, a poza tym nie wiem nic i modlę się ${ }^{44}$.

\footnotetext{
39 Tamże, s. 324.

40 Tamże, s. 359.

41 Tamże, s. 108.

${ }^{42}$ Rękopis w: AFSK, sygn. 452 (s. Maria Gołębiowska - Miriam Wajngold).

43 Tak sie zaczęto..., dz. cyt., s. 462.

${ }^{44}$ J. Liebert, Listy do Agnieszki, dz. cyt., s. 402-403.
} 
Krótko potem zdecydowała się na powrót do Polski. Jak ważne były dla niej te słowa, świadczy przechowywane razem z fotografiami osób jej najbliższych zdjęcie Lasek, na którego odwrocie je zapisała.

Do Polski wróciła na początku sierpnia 1926 roku. „Przyjechałam na Polną - wspominała - wszystko mi się strasznie podobało, zupełne ubóstwo, zupełna prostota”45. Przy przywołanej tutaj ul. Polnej $40 \mathrm{w}$ Warszawie mieścił się wówczas zakład dla niewidomych dziewcząt prowadzony przez Towarzystwo Opieki nad Ociemniałymi we współpracy ze Zgromadzeniem Sióstr Franciszkanek Służebnic Krzyża. Obie instytucje zostały założone przez Różę Czacką (towarzystwo w 1911 roku, zgromadzenie w 1918 roku). Do tego zgromadzenia wstąpiła Bronisława. Została siostrą Miriam od Kościoła Bożego, pierwszą po zmarłej s. Katarzynie Sokołowskiej siostrą w zgromadzeniu, która wywodziła się z kręgów inteligenckich. Była też, jak jej poprzedniczka, równie radykalna. Po przeczytaniu książki o św. Franciszku chciała go naśladować i rozdała wszystko, co miała. Zrobiła tym kłopot Matce Czackiej, bo trzeba jej było kupić najpotrzebniejsze rze$\mathrm{czy}^{46}$. Ten wewnętrzny radykalizm zachowała w sobie do końca życia.

Decyzja Agnieszki była dla Lieberta trudna do przyjęcia. W jego listach pojawia się smutek i rezygnacja. „Będzie tak, jak chce Pan Jezus - pisał 26 marca - choć On widzi, że te słowa więcej mnie kosztowały, niż przypuszczałem. (...) co będzie ze mną i jakimi drogami zechce mnie Bóg poprowadzić? Dlaczego myśląc o Twoim postanowieniu widzę tylko rozłączenie, a nie nasze spotkanie w Panu Jezusie?”7 Rozpacz, która go ogarnęła, starał się przed nią ukrywać. Tylko raz, w liście z 2 kwietnia, napisanym po rekolekcjach dla Kółka prowadzonych przez ks. Korniłowicza w Mordach, powiedział nieco więcej:

Po milczeniu i ciągłym łamaniu siebie samego, natura moja zbuntowała się. Była chwila, kiedy chciałem rzucić wszystko. Ten dzień był załamaniem, z którego wyszedłem zwycięsko. (...) Gdy już przy końcu byłem zmęczony tymi szarpaniami przez parę dni, gdy mu powiedziałem, jaki grzeszny smutek zapanował we mnie na wieść o Twojej decyzji, objął mnie w ramiona i tak już przetrwaliśmy do końca. Siostrzyczko, on mnie usprawiedliwiał $(\ldots)^{48}$.

Ślad tych zmagań znajdujemy też w jego poezji. Jakby na dwóch biegunach - odczuwanego na przemian buntu i pogodzenia się z losem - mieszczą się dwa jego wiersze, które powstały w tym czasie - Zaślubiny ${ }^{49} \mathrm{i}^{* * *}\left(W_{s z e l k a}\right.$ taska, której imię) $)^{50}$. Zaślubiny to słowa człowieka do głębi rozdartego, wręcz

45 Tak się zaczęto..., dz. cyt., s. 463-464.

${ }^{46}$ s. M. Gołębiowska, Pamiętnik 1978-1980 (notatki dotyczące życia w zgromadzeniu), rps, AFSK, sygn. 452.

47 J. Liebert, Listy do Agnieszki, dz. cyt., s. 385-386.

48 Tamże, s. 387.

49 Tenże, Zaślubiny [w:] tegoż, Gusta, Warszawa 1930, s. 28.

${ }^{50}$ Tenże, *** (Wszelka taska, której imię) [w:] tegoż, Pisma, t. 1: Poezje, dz. cyt., s. 82. 
wypalonego, pozbawionego marzeń, z kolei drugi wiersz, bez tytułu, ma już w sobie zalążek przyszłego pogodzenia się sytuacją, widoczny w zakończeniu: „Wszelka łaska Pańska/ Niech spłynie na umysł i serce siostry mojej Agnieszki/ A gorzki smutek rozstania zabierze ode mnie" 51 .

Pustkę po odejściu Agnieszki dopiero dwa lata później zagłuszył związek z inną kobietą, Marią Leszczyńską, od której - jak pisał Stefan Frankiewicz „dzielił poetę cały świat budowanej w sobie przez lata wiary” ${ }^{52}$. Jedną rozpacz poeta zastąpił drugą:

Uczuciowy związek z osobą dwukrotnie przedtem zamężną zadecydował o tym, że poeta sam oddalił się od wielu dawnych przyjaciół, od Lasek. Dotkliwie cierpiał, uważając swoją nową sytuację za nienormalną z punktu widzenia do końca wyznawanej wiary. Swoją nową udręką dzielił się głównie z Rafałem Blüthem i Zygmuntem Serafinowiczem, bratem Lechonia ${ }^{53}$.

Agnieszka, wówczas nowicjuszka w Laskach, o tym, co się dzieje z przyjacielem, dowiadywała się już nie z jego listów (ostatni datowany jest na 23 stycznia 1928 roku), ale od wspólnych przyjaciół.

Łatwo i błędnie można byłoby uznać jej milczenie za dowód nieczułości. Chociaż bardzo boleśnie wszystko to przeżywała, niewiele osób i wtedy, i później o tym wiedziało. Stefan Frankiewicz, wydawca Listów do Agnieszki, był jedną z nielicznych osób, przed którymi wiele lat później uchyliła nieco zasłonę milczenia, jaką się wówczas otoczyła. $\mathrm{O}$ wszystkim z pewnością wiedziała Matka Elżbieta Czacka. Znała ją przecież doskonale, skoro cały okres swojego postulatu Agnieszka spędziła, jak sama mówiła, „przy Mateńce” - była jej sekretarką, lektorką i przewodniczką. W marcu 1929 roku, gdy Agnieszka, wówczas już nowicjuszka s. Miriam, nie widziała przed sobą nic prócz burzy, zamętu i ciemności, Matka Czacka z właściwą sobie delikatnością jej tłumaczyła:

Bóg spojrzał z miłością na Ciebie i dla Twojego dobra burzy i przewraca wszystko w Tobie i wkoło Ciebie. Trudno Ci zrozumieć, co się dzieje, zdaje Ci się chwilami, że wszystko stracone, że źle z Tobą się dzieje, że wszystko przepadło i cierpisz, cierpisz bardzo. Trwoga Cię chwilami ogarnia, ciemności, rozterka i głuchy ból. Burza chwilami w Twojej duszy szaleje, wszystko niszczy i przewraca, co zdawało się być już mocnym i ugruntowanym. W tej burzy, w tym bólu, w tym zamęcie jest miłosierna i kochająca Cię w szczególny sposób Ręka Boga. (...) Ty w tej chwili nie rozumiesz, co się z Tobą i wkoło Ciebie dzieje, ale Bóg celowo, spokojnie i mocno, dzieła swego dokonywa ${ }^{54}$.

51 Tamże.

52 S. Frankiewicz, Wstęp [w:] J. Liebert, Listy do Agnieszki, dz. cyt., s. 17.

53 Tamże.

${ }^{54}$ List Matki Czackiej do s. Miriam Wajngold (Marii Gołębiowskiej) z dn. 27 marca 1929 [w:] Ludzie Lasek, dz. cyt., s. 464. 
Posłuszna wskazaniom Matki Czackiej, która zalecała jej modlitwę i wierne spełnianie wszystkich, nawet najnudniejszych obowiązków, każdego dnia, jakby wbrew własnemu cierpieniu, podejmowała trud codziennej pracy. W 1928 roku pracowała w domu św. Antoniego, gdzie opiekowała się dziewczętami, a od stycznia 1929 do 1931 roku w administracji domu św. Teresy i w mieszczącym się tam internacie chłopców. Zachowały się dwa jej zdjęcia $\mathrm{z}$ tego okresu. $\mathrm{Na}$ jednym $\mathrm{z}$ nich siedzi z grupą niewidomych dziewcząt na murku okalającym kaplicę. Dziewczęta czytają książki, a ona choć im towarzyszy, jest jakby nieobecna - zapadnięta głęboko w sobie. Co dzień na nowo, konsekwentnie potwierdzała raz podjętą decyzję, o której napisała w swoim wierszu z 1933 roku, zatytułowanym Tak:

W stukaniu drzwi, w tupocie nóg,

Wśród gwaru słów, w zamęcie spraw,

Najsłabsza z słabych Twoich sług

Najtwardsze wciąż powtarzam: tak ${ }^{55}$.

I znów, jakże blisko jej było do Jerzego Lieberta, który w jednym z najsłynniejszych swoich wierszy napisał:

Jedno wiem, i innych objawień

Nie potrzeba oczom i uszom -

Uczyniwszy na wieki wybór,

W każdej chwili wybierać muszę ${ }^{56}$.

Wszystko to, co się w niej i wokół niej działo, przeżywała - jak pisał Stefan Frankiewicz - „w perspektywie osobistej wierności Bogu i podjętemu postanowieniu, a jednocześnie wierności człowiekowi, za którego nie mogła nie czuć się odpowiedzialna" ${ }^{57}$. Musiała wyjść z tej próby zwycięsko, skoro 6 stycznia 1930 roku złożyła swoje pierwsze śluby zakonne, a sześć lat później śluby wieczyste. Poczucie odpowiedzialności za przyjaciela dźwigała jednak przez całe swoje życie. Przejawiało się ono nie tylko w dbałości o spuściznę literacką Lieberta, ale także - może nawet przede wszystkim - w trosce, jaką otaczała każdego napotkanego człowieka, w tej potrzebie towarzyszenia ludziom, jaką wszyscy w niej dostrzegali, oraz w ogromnej dla nich wyrozumiałości. Wszystkie te, tak bardzo podziwiane cechy jej charakteru, wykuwały się właśnie w chwili tej ciężkiej próby. Wkrótce też nadszedł czas ich sprawdzenia. Jerzy Liebert zmarł 19 czerwca 1931 roku na gruźlicze zapalenie opon mózgowych, a jego

55 S. Maria Gołębiowska, Wiersze, mps, s. 11, AFSK, sygn. 452 (s. Maria Gołębiowska s. Miriam Wajngold). Tekst został opublikowany przez S. Frankiewicza, w jego tekście Agniesz$k a$, dz. cyt., s. 452-453.

56 J. Liebert, Jeździec [w:] tegoż, Gusta, dz. cyt., s. 50.

57 S. Frankiewicz, Agnieszka [w:] Ludzie Lasek, dz. cyt., s. 449. 
towarzyszka, Maria Leszczyńska, po jego śmierci przeszła gwałtowne załamanie nerwowe. Trafiła najpierw do szpitala psychiatrycznego w Tworkach, a później do Lasek, gdzie pod czułą opieką s. Miriam wracała do równowagi.

W pierwszych latach drugiej wojny światowej życie s. Miriam niczym się nie różniło od życia innych sióstr w Laskach. Sytuacja zmieniła się na początku 1942 roku, gdy pojawiły się pierwsze pogłoski, że Niemcy zaczęli się interesować laskowskimi siostrami pochodzenia żydowskiego. W Zgromadzeniu Sióstr Franciszkanek Służebnic Krzyża było ich wówczas cztery - s. Teresa Landy, s. Katarzyna Steinberg, s. Miriam Wajngold i s. Bonifacja Goldman. Ta ostatnia była niewidoma, więc na początku września 1939 roku wraz z podopiecznymi zakładu udała się do Żułowa. Ponieważ nigdy nie pełniła żadnych eksponowanych funkcji ani w zgromadzeniu, ani w towarzystwie, właściwie nie musiała się ukrywać. W miarę bezpieczna wydawała się również s. Teresa Landy, która znajdowała się wówczas w Żułowie. Najbardziej zagrożone były przebywające w Laskach - s. Katarzyna i s. Miriam.

W 1974 roku, na prośbę swojej przełożonej, s. Maria opisała swoje okupacyjne losy i to, co wówczas czuła. Zanotowała:

O ile dobrze pamiętam do zimy 1942 r. nie zdawałam sobie sprawy z tego, że i mnie - z racji pochodzenia - może grozić niebezpieczeństwo. Nienawiść rasowa - a więc i antysemityzm - była dla mnie zawsze czymś nad wyraz bolesnym i trudnym do zrozumienia. Mniej więcej w pierwszych miesiącach 1942 r. Matka Czacka poleciła s. Benedykcie, s. Joannie i s. Odylli zorientować się i wyszukać dla nas paru, pochodzenia żydowskiego, bezpiecznych miejsc na przeżycie wydawało się kończących się miesięcy wojny. Powiedziano mi o tym i wiadomość ta budziła we mnie sprzeciw, nie mogłam pogodzić się z myślą opuszczenia Lasek, skąd od sierpnia 1926 r. nie wyjeżdżałam i gdzie jedynie czułam się bezpieczna. (...) Powiedziano mi, że wreszcie s. Joanna czy s. Benedykta porozumiały się z siostrami Zgromadzenia Sióstr Rodziny Marii. W ich domu warszawskim, w klauzurze, ale ubrana po świecku miałam się ukrywać ${ }^{58}$.

Stało się jednak inaczej. W połowie maja świeccy pracownicy zakładu zostali powiadomieni przez granatową policję, że pojawił się donos, iż niektóre siostry w klasztorze są Żydówkami. Matka Czacka zdecydowała, że s. Miriam i s. Katarzyna muszą natychmiast wyjechać.

„Byłam zrozpaczona” - krótko skwitowała to później w swoich wspomnieniach s. Maria. Jej stan emocjonalny musiał być aż nadto widoczny, skoro jedna z laskowskich sióstr, Klara Jaroszyńska, zdecydowała się opuścić klasztor, by się nią opiekować5 ${ }^{59}$ „Z całą ufnością - mówiła o niej później s. Maria - zawierzyłam jej swój los" 60 .

58 [s. M. Gołębiowska], Okupacja 1942-1945 [w:] Ludzie Lasek, dz. cyt., s. 465-466.

59 Wypowiedzi s. Klary, nagranie video, CD w: AFSK.

${ }^{60}$ [s. M. Gołębiowska], Okupacja 1942-1945, dz. cyt., s. 466. 
Siostra Klara, podejmując tę decyzję, miała 31 lat, jej „podopieczna” była wprawdzie dziewięć lat starsza, ale życiowo - jak się zdaje - znacznie mniej zaradna. Dopiero wyjazd z Lasek w pełni uświadomił siostra Miriam grozę jej sytuacji. „Pamiętam - pisała - że wpadłam w depresję, leżałam, płakałam i modliłam się o Bożą pomoc"61. Najpierw ukrywała się w Warszawie u rodziców s. Klary - Marii i Józefa Jaroszyńskich. Ponieważ w ich mieszkaniu ukrywało się już wówczas troje żydowskich dzieci, zdecydowano, że dla bezpieczeństwa wszystkich siostry wyjadą do Zakopanego, gdzie miały znaleźć schronienie w klasztorze szarych urszulanek na Jaszczurówce. Plan się nie powiódł. Odmówiono im zameldowania, ponieważ Zakopane zostało właśnie wtedy ogłoszone strefą przeznaczoną wyłącznie dla Niemców. Przeniosły się więc do zmartwychwstanek w Bukowinie Tatrzańskiej pod pretekstem choroby płuc s. Marii, co było zresztą zgodne z prawdą. Siostra Miriam była już wówczas s. Marią Gołębiowską. Miała fałszywą metrykę chrztu i prócz niej żadnych innych dokumentów, więc s. Klara również zniszczyła swój dowód, a następnie niemal cudem zdobyła z urzędu gminy „kenkarty” dla nich obu. Szczęśliwie udało jej się to osiągnąć tuż przed ogłoszeniem zarządzenia, że do ich wydania trzeba złożyć dowód osobisty.

Choć bukowiński klasztor wydawał się miejscem bezpiecznym, nie czuły się tam dobrze. Siostra Maria, ogarnięta przerażeniem, niewiele jadła i nie spała po nocach. Miejscowy ksiądz bez przerwy przestrzegał siostry, by nie pomagały Żydom, a one coraz częściej powtarzały, że skoro nie otrzymują żadnych listów, to z pewnością są ukrywającymi się Żydówkami. Zdecydowały się więc opuścić klasztor i wynająć izbę w niewykończonej góralskiej chałupie bez okien. Za ścianą miały pomieszczenia dla zwierząt. Żyły z własnej pracy i niewielkich sum pieniędzy otrzymywanych z Lasek. Towarzyszyło im ciągłe napięcie: „Każde obce kroki, skrzypienie śniegu, podrywało nas na nogi. Ale cały czas byłyśmy razem" ${ }^{\prime 2}$.

Siostra Maria, obyta z biedą w Laskach, znosiła ją znacznie lepiej niż to, że musiała się ukrywać i tym samym narażała otaczających ją ludzi na śmiertelne niebezpieczeństwo. $Z$ jednej strony pragnęła uczciwie wyznać prawdę o swoim pochodzeniu, z drugiej zaś wiedziała, że decyzja o ujawnieniu się byłaby równoznaczna z wyrokiem śmierci dla tych, którzy ją ukrywali. Pomagali im miejscowi górale. Za wynagrodzenie „w naturze” s. Maria szyła, haftowała i cerowała góralskie chusty, a s. Klara pracowała w polu, prała i sprzątała chałupy, pilnowała dzieci i jako pielęgniarka odwiedzała chorych. Zorganizowały również komplety. Siostra Klara uczyła dzieci młodsze, a s. Maria - starsze. W lipcu 1944 roku musiały tę działalność przerwać, gdyż doniesiono im, że Niemcy się o nich dowiedzieli.

61 Tamże, s. 466.

62 Cyt. za: P. Bukalska, Jak Bóg dat zadanie, to i dat odwage, http://www.dialog.org/hist_ pl/spotkanie-po-60-latach.html, dostęp: 1.07.2011. 
Gdy jedzenia nie starczało, s. Klara jeździła „kwestować” do Krakowa. Z jednego z takich wyjazdów w 1942 roku przywiozła trzyletnie żydowskie dziecko - Ewunię, która cudem uniknęła transportu do Treblinki ${ }^{63}$. Wkrótce potem dołączyła do nich Halinka Lautenberg ukrywająca się dotąd w mieszkaniu państwa Jaroszyńskich w Warszawie, a także przez pewien czas s. Teresa Landy, gdy musiała opuścić klasztor karmelitanek w Czernej pod Krakowem. Swoje wojenne wspomnienia s. Maria zakończyła stwierdzeniem doskonale charakteryzującym postawę s. Klary: „Swoją wesołością, humorem, zaradnością stworzyła atmosferę bezpieczeństwa, dzięki której przetrwałam ciężkie lata; wierzę, że uratowała mi zdrowie, a może i życie" ${ }^{64}$. Jesienią 1945 roku obie siostryMaria i Klara - wróciły do Lasek, niemal zupełnie zniszczonych w czasie wojny.

Wojenne doświadczenia s. Marii przez wiele lat pozostawały okryte zasłoną milczenia. Nic w tym dziwnego. W Polsce raczej się wówczas o tym nie wspominało. Siostra Maria nie wróciła ani do swojego dawnego imienia zakonnego, ani do nazwiska. Doświadczenia czasu wojny ciągle były zbyt silne, a powtarzające się wybuchy antysemityzmu napawały niepokojem.

O swoim pochodzeniu, nawet osobom najbliższym, mówiła niezwykle rzadko i powściągliwie. Pamiętam, jak bolesnym przeżyciem były dla niej wydarzenia 1968 roku i ich konsekwencje w biografiach konkretnych ludzi; pamiętam też, z jakim smutkiem reagowała na dające o sobie znać resentymenty w postawie ludzi bliżej związanych z Kościołem - tą instytucją, którą jak mało kto darzyła ogromnym zaufaniem i dziecięcą wprost miłością ${ }^{65}$.

Niezależnie od zajmowanego przez nią stanowiska, a było ich wiele, jedno pozostawało niezmienne - jej otwartość na potrzeby drugiego człowieka i bezinteresowność przyciągały ludzi do Lasek. Nigdy nie była obojętna wobec cudzych problemów, ani się nimi nie gorszyła: „Niczemu się nie dziwiła, na nic się nie oburzała - wspominała s. Elżbieta Więckowska. - Potrafiła, gdy było trzeba, zganić lub upomnieć bardzo stanowczo, ale nie było w tym żadnego niepokoju. Nigdy nie prowokowała zwierzeń i nie dopytywała, czuło się w tym Jej wielki szacunek do drugiego człowieka"66. Krąg jej przyjaciół obejmował różne środowiska - zarówno literackie, z racji jej przeszłości, jak i te związane z działalnością opozycyjną, pozostające zresztą w bliskich relacjach ze środowiskiem literatów i ludzi kultury ${ }^{67}$. Z pewnością jednak w swo-

63 Wypowiedzi s. Klary, nagranie wideo, dz. cyt.

${ }^{64}$ [s. M. Gołębiowska], Okupacja 1942-1945, dz. cyt., s. 466.

65 S. Frankiewicz, Agnieszka, dz. cyt., s. 444.

${ }^{66}$ Cyt. za: s. M.J.L. Witkowska, Macierzyństwo duchowe siostry Marii Gotębiowskiej (19021984), franciszkanki z Lasek, mps, Archiwum FSK.

${ }^{67} \mathrm{Nie}$ ma tu miejsca, by rozwinąć kwestię związków tych środowisk z Laskami, choć temat ten ciągle pozostaje nieopracowany i warto byłoby poświęcić temu zagadnieniu osobną publikację. Wśród książek, które nieco go naświetlają, należy zwrócić uwagę na: A. Friszke, Oaza 
ich przyjaźniach nie skupiała się specjalnie na żadnej z tych grup. Wprawdzie czasem mówiono o niej, że jest w Laskach siostrą „od pisarzy” albo - głównie z powodu przyjaźni z Tadeuszem Mazowieckim - siostrą „od opozycjonistów”, to takie ujęcie nie oddaje prawdy o s. Marii, która w swoich przyjaźniach nie zważała na żadne przynależności. W swoim testamencie napisała po prostu: ,Jedno wiem na pewno: kochałam ludzi, każdego, z którym się spotkałam, każdego człowieka"68.

Dokument ten, napisany w 1979 roku, a więc pięć lat przed jej śmiercią, i zaadresowany do o. Tadeusza Fedorowicza, odsłonił jedną z jej wielkich tajemnic:

Zbliża się kres mojego życia. Coraz lepiej rozumiem, że trzeba Bogu oddać wszystko, także złudzenia, że jestem potrzebna i że współpracuję i współtworzę życie w Laskach, życie Zgromadzenia i życie Dzieła. (...) Przed Ukrzyżowanym Chrystusem trzeba bym stanęła w całej prawdzie. Małoduszność, tchórzostwo - to moje największe wady. Od 34 lat wyrzucam sobie, że nie powróciłam do mojego imienia nadanego mi przez Ojca Korniłowicza i do nazwiska mojego rodzonego Ojca. Lęk przed antysemityzmem i sentymentalna wdzięczność dla nazwiska, które ratowało w czasie okupacji - a właściwie brak umiłowania prawdy ${ }^{69}$.

Bywała twarda wobec otaczających ją ludzi, ale najbardziej wymagająca była wobec samej siebie. „Jestem - pisała w swoich notatkach - jak piasek, na którym Chrystus pisze palcem jeden wyraz: skrucha"70.

Po jej śmierci zaprzyjaźniona z nią poetka, Anna Kamieńska, napisała:

Zostaje jeszcze za wiele cienka tkanina na przedmiotach

książkach i słowach

tym którym śpieszy się zniknąć

nawet śmierć nie wydaje się dość dokładna

czytam sny twoje siostro spod pierwszego śniegu

spod dziewiczego zawoju

twarz już niewidocznieje

a jeszcze pogłębia się uśmiech nieodgadniony ${ }^{71}$.

na Kopernika. Klub Inteligencji Katolickiej 1956-1989, Warszawa 1997; W. Rodziewicz, Komitet na Piwnej: fakty, dokumenty, wspomnienia, Warszawa 1994, a także ujęte z szerszej perspektywy: A. Micewski, Wspótrządzić czy nie ktamać. PAX i Znak w Polsce 1945-1976, Paryż 1978.

${ }_{68}$ Testament [w:] Ludzie Lasek, dz. cyt., s. 474.

69 Tamże.

70 Notatki (przypuszczalnie z 1976 roku), rps, Archiwum FSK.

${ }^{71}$ A. Kamieńska, Pamięci s. Marii z Lasek [w:] tejże, Milczenia i psalmy najmniejsze, Kraków 1988, s. 152. 
$\mathrm{Na}$ grobie, zgodnie z jej życzeniem wyrażonym w testamencie, zawisła tabliczka z dwoma imionami i nazwiskami - s. Maria od Kościoła Bożego Miriam Wajngold Gołębiowska.

\section{Bibliografia}

Źródła archiwalne (niedrukowane):

Archiwum Franciszkanek Służebnic Krzyża (AFSK): sygn. 452 (s. Maria Gołębiowska - s. Miriam Wajngold), sygn. 452 (s. Katarzyna - Zofia Steinberg).

\section{Źródła drukowane:}

Kamieńska A., Milczenia i psalmy najmniejsze, Kraków 1988.

Liebert J., Druga ojczyzna, Warszawa 1925.

Liebert J., Gusta, Warszawa 1930.

Liebert J., Kotysanka jodtowa, Warszawa 1932.

Liebert J., Listy do Agnieszki, red. S. Frankiewicz, Warszawa 2002.

Liebert J., Pisma, t. 1: Poezje, przedm. L. Staff, Warszawa 1934.

Liebert J., Pisma zebrane, oprac. i wstęp S. Frankiewicz, t. 1-2, Warszawa 1976.

[s. M. Gołębiowska], Okupacja 1942-1945 [w:] Ludzie Lasek, oprac. i wstęp T. Mazowiecki, Warszawa 2000.

[s. M. Gołębiowska], Tak się zaczęto... (Z teki archiwalnej siostry Marii) [w:] Ludzie Lasek, oprac. i wstęp T. Mazowiecki, Warszawa 2000.

[s. M. Gołębiowska], Testament [w:] Ludzie Lasek, oprac. i wstęp T. Mazowiecki, Warszawa 2000.

\section{Opracowania:}

Bukalska P., Jak Bóg dat zadanie, to i dat odwage, http://www.dialog.org/hist_pl/ spotkanie-po-60-latach.html, dostęp: 1.07.2011.

Cwalina T., Kartki z cmentarza, Warszawa-Laski 2010.

Cwalina T., List Agnieszki, „Laski. Pismo Rehabilitacyjno-Społeczne z Życia Dzieła Matki Elżbiety Róży Czackiej” 2004, nr 6.

Cywiński B., Rodowody niepokornych, Warszawa 2010.

Frankiewicz S., Agnieszka [w:] Ludzie Lasek, oprac. i wstęp T. Mazowiecki, Warszawa 2000.

Friszke A., Oaza na Kopernika. Klub Inteligencji Katolickiej 1956-1989, Warszawa 1997.

Jabłońska-Deptuła E., Matka Elżbieta Czacka i dzieto Lasek, Lublin 2002.

Landy T., Wosiek R., Ksiadz Wtadystaw Kornitowicz, Warszawa 2003.

Lęki, ucieczki, akceptacje, red. I. Smolka, Warszawa 1984.

Lichniak Z., Poeta konsekwencji. Rzecz o Jerzym Liebercie, Warszawa 1952.

Ligęza W., Epitafia dla skamandrytów, Kraków 1996.

Ludzie Lasek, oprac. i wstęp T. Mazowiecki, Warszawa 2000. 
Łukasiewicz J., Ruch i trwanie - Jerzy Liebert [w:] Poeci dwudziestolecia międzywojennego, red. I. Maciejewska, Warszawa 1982.

Marx J., Skamandryci: Julian Tuwim, Kazimierz Wierzyński, Jarostaw Iwaszkiewicz, Antoni Stonimski, Jan Lechoń, Stanistaw Balinski, Warszawa 1993.

Meandry skamandrytów, red. W. Appel, Toruń 2011.

Micewski A., Wspótrzadzić czy nie ktamać. PAX i Znak w Polsce 1945-1976, Paryż 1978.

Misiniec S., Ślady na niebie. Duchowa droga Jerzego Lieberta, Kraków 1997.

Mocarska Z., Poeta doświadczenia religijnego, „W drodze” 1977, nr 6.

Nowaczyński P., Studia z literatury XX wieku, Lublin 2004.

Polska liryka religijna, red. S. Sawicki, P. Nowaczyński, Lublin 1983.

Przybył-Sadowska E., Biblioteka Wiedzy Religijnej w Warszawie (1919-1939), „Z Badań nad Książką i Księgozbiorami Historycznymi” 2016, nr 10.

Przybył-Sadowska E., Triuno. Instytucje we wspólnocie Lasek 1911-1961, Kraków 2015. Reinterpretacje, „Skamander”, t. 11, red. M. Tramer, A. Wójtowicz, Katowice 2015.

Rodowicz W., Komitet na Piwnej: fakty, dokumenty, wspomnienia, Warszawa 1994.

Sadkowska-Mokkas L., Warszawa Skamandrytów, Warszawa 2016.

Sawicki S., Religijny horyzont poezji, Lublin 2000.

Smaszcz W., Habitus poetycki Jerzego Lieberta [w:] J. Liebert, Poezje wybrane, Warszawa 1996.

Stradecki J., W kregu Skamandra, Warszawa 1977.

Stulecie skamandrytów, red. K. Biedrzycki, Kraków 1996.

Szczepan-Wojnarska A.M., „...Z ogniem będziesz się żenit”. Doświadczenie transcendencji w życiu i twórczości Jerzego Lieberta, Kraków 2003.

Reinterpretacje, „Skamander”, t. 11, red. M. Tramer, A. Wójtowicz, Katowice 2015.

Wiśniewska E., Jerzy Liebert w mistycznej walce o stowo, „Przegląd Powszechny” 1982, nr 5.

Witkowska M.J.L., Macierzyństwo duchowe siostry Marii Gotębiowskiej (19021984), franciszkanki z Lasek, mps, AFSK. 